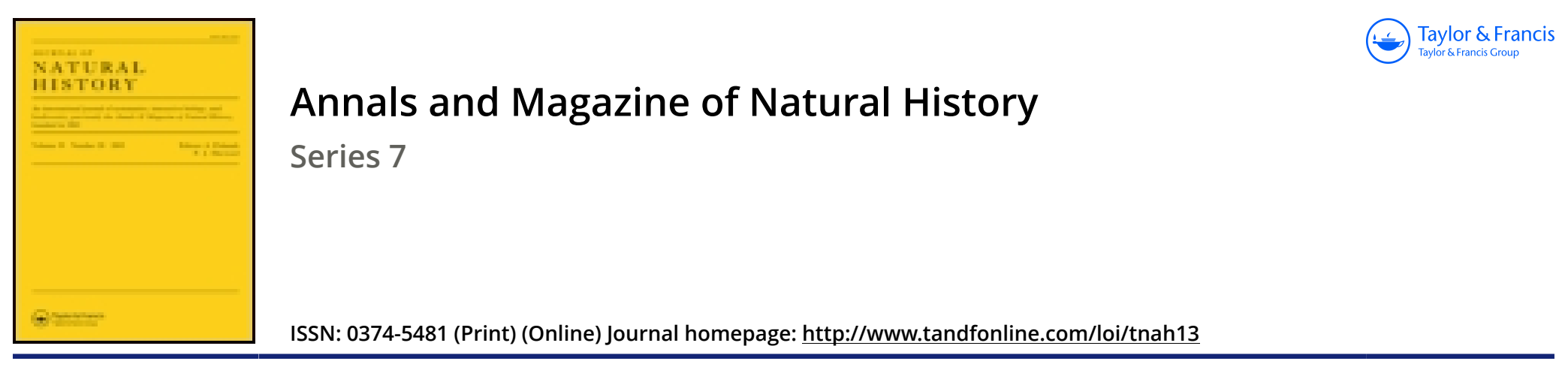

\title{
LVIII.-On Macrurous Crustacea obtained by Mr. George Murray during the cruise of the 'oceana' in 1898
}

\section{W.T. Calman D.Sc.}

To cite this article: W.T. Calman D.Sc. (1903) LVIII._On Macrurous Crustacea obtained by Mr. George Murray during the cruise of the 'oceana' in 1898, Annals and Magazine of Natural History, 11:64, 416-420, DOI: 10.1080/00222930308678791

To link to this article: http://dx.doi.org/10.1080/00222930308678791

曲 Published online: 29 Sep 2009.

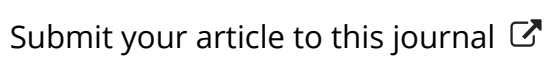

Џll Article views: 2

Q View related articles $\sqsubset$ 
LVIII.-On Macrurous Crustacea obtained by Mr. George Murray during the Cruise of the 'Oceana' in 1898*. By W. T. Calman, D.Sc., University College, Dundee.

Tre Macrurous Crustacea sent to me for examination by Mr. George Murray, F.R.S., are all of small size and all, with one possible exception, immature. Only one could be referred with any confidence to a species already described; but I have not thought it necessary to give more than brief descriptions of the solitary specimens of the other species. In addition, there will be found below some remarks on the characters and synonymy of the genus Amalopenceus and on the order of development of the gills in Pasiphaa. A specimen of Sergestes which proves to belong to a new species will be separately reported on by Dr. H. J. Hansen of Copenhagen.

\section{Family Penæidæ.}

\section{Amalopenaus elegans, S. I. Smith.}

Amalopenaus elegans, S. I. Smith, Rep. Crust. 'Blake,' Bull. Mus. Comp. Zool. Harvard, x. pp. 87-91, pl. xiv. fig8. 8-14, pl. xv. figs. 1-5 (1882) ; Hansen, "Malacostraca marina Gronlandia occidentalis," Vidensk. Meddel. fra den naturh. Foren. i Kjöbenhavn, 1887, p. 52; Ortmann, Decapoden u. Schizopoden d. Plankton-Expedition, pp. $27-28$ (1893).

Locality. Lat. $52^{\circ} 18^{\prime}$ N., long. $15^{\circ} 53^{\prime} 9^{\prime \prime}$ W. Net no. $5 h$. 1410 fath. $\dagger$ 21/11/98. One specimen.

The specimen recorded under this name is an immature male about 20 millim. in length, $i$. e, about two thirds of the length of the smallest specimen recorded by Smith, with whose excellent description and figures, however, it agrees minutely, except in the one detail, to which Hansen has already called attention, that the upper edge of the rostrum is microscopically serrate. The genital appendages of the first pair of pleopods ("petasma") are of small size and imperfectly developed, but the various lobes and processes indicated by Smith can all be identified. When first received the specimen (preserved in formalin) retained to a considerable extent the striking coloration referred to by Smith, the anterior appendages, and especially the maxillipeds, being more or less suffused with bright purple, while the marginal setæ of these limbs were of a brilliant scarlet.

* See Jouru. Geograph. Soc. vol. xiii. no. 2, Feb. 1899.

+ The method of capture was that of open tow-nets in series; the depth given in relation to each net refers to the computed position of the net. 
By recent writers the genus Amalopencens of Smith has generally been regarded as synonymous with the earlier Gennadas of Spence Bate $*$, and it has been suggested $\dagger$ that of the two imperfectly described species referred to the lastnamed genus by Spence Bate, G. parvus, and possibly also $G$. intermedius, may be specifically identical with $A$. elegans. Both Ortmann and Faxon $f$, however, call attention to the important difference in the branchial formulæ assigned to these two genera. Amalopenceus was stated by Smith to possess only one podobranch, attached to the second maxilliped, in contradistinction to the closely allied Benthesicymus, where five podobranchs are present; for Gennadas, on the other hand, Spence Bate gives a formula agreeing in this respect with that of Benthesicymus. Ortmann, in recording A. elegans from the Plankton Expedition, states that his specimens agreed with those of Smith in this as in all other respects, and suggests that some error has crept into Spence Bate's formula for Gennadas. This solution of the difficulty might well have been accepted were it not that Alcock $\$$, referring to G. parvus specimens from Indian seas, states that the genus, and by implication this species, does not differ from Benthesicymus in the number of its gills.

On account of the small size of the present specimen, the determination of its complete branchial formula is a matter of some difficulty; but it can be seen without doubt that it is devoid of podobranchs on the peræopods, and that in so far it agrees with $A$. elegans and differs from $G$. parvus. I am unable to point out any other characters of importance whereby it may be distinguished from the last-named species. Spence Bate's figure of the third maxilliped of G. parvus shows the ischial and meral joints subequal in length, while in our specimen, as in Smith's figure, the ischium is nearly twice as long as the merus; the eye-stalk is not more than one fifth of the length of the carapace (in Spence Bate's figure the proportion is about one third) and is proportionately slender, while the whole body is less robust than in the figure. None of these differences, apart from the branchial formula, are sufficient to decide the question of the specific distinctness of the two forms.

* Ann. \& Mag. Nat. Hist. (5) viii. p. 191 (1881), and Rep. Crustacea Macrura 'Challenger,' p. 339 (1888).

$\dagger$ Wood-Mason and Alcock, Ann. \& Mag. Nat, Hist. (6) vii. p. 189 (1891), and Ortmann, l.c.

f "Stalk-eyed Orust. 'Albatross,'" Mem. Mus. Comp. Zool. Harvard, xviii. p. 208 (1895).

$\S$ Cat. Indian Deep-Sea Macrura and Anomala, p. 45 (1901).

Ann. \& Mag. N. Hist. Ser. 7. Vol. xi. 
The evidence given below as to the late appearance of certain gills in Pasiphea might, perhaps, suggest that the apparent absence of podobranchs in our specimen was merely a character of immaturity, were it not that Smith's much larger specimens, with which it agrees in this respect, appear to have been quite mature. All that can be said at present is that our specimen confirms the original account of the gill-formula of Amaloperaus and leaves undecided the question of its identity with Gennadas.

Distribution. A. elegans is recorded by Smith from various localities off the east coast of the United States at depths of 372-1632 fathoms; by Hansen from West Greenland (from stomach of a fish); and by Ortmann from the Sargasso Sea, 1300-1500 m. (closing tow-net), and south of the Cape-Verde Islands, $0-400 \mathrm{~m}$. (vertical net). G. parvus was obtained by the 'Challenger' at numerous stations in the Atlantic and Pacific Oceans at depths of from 345-3050 fathoms, and is recorded by Aleock from the Bay of Bengal and the Arabian Sea at 738-1043 fathoms. G. intermedius was found by the 'Challenger' at the surface and at a depth of 1850 fathoms in the Atlantic.

\section{Family Pasiphæidæ.}

\section{Pasiphae sp.}

Locality. Lat. $52^{\circ} 27^{\prime} 6$ N., long. $15^{\circ} 40^{\prime}$ W. Net no. $4 k$. 1670 fath. 20/11/98. One specimen.

The total length of the specimen is about 17 millim., of which the carapace occupies rather more than one third. The body is only slightly compressed. The rostrum has the form of a forwardly directed, compressed, triangular tooth extending to the middle of the length of the eye-stalks; it is continued backwards by a ridge on the dorsal surface of the carapace, rising slightly to form a low, obtusely triangular prominence at about one third of the length of the carapace from the front, and becoming obsolete posteriorly. The sides of the carapace present several obscurely marked ridges and impressed lines, a horizontal ridge running backwards along the branchial region being the most conspicuous. The sixth abdominal somite is about twice as long as the fifth. The telson is transversely truncated at the tip and is shorter than the exopod and subequal to the endopod of the uropods. The eyes are small, not wider than their stalks, the corneal surface obliquely placed, faintly pigmented, and with a blunt tubercle above on the inner side. The mandibles have no palp. The other mouth-parts agree closely with those of 
Pasiphra. The chelipeds of the first pair are shorter than the second, the merus has a few setæ on its lower edge, and the palm is but little longer than the fingers. The second pair have the merus armed with five spines on its lower edge and the chela is more slender and longer by one half than that of the first pair. The fourth pair of legs are a little less and the fifth pair a little more than one half the length of the third pair.

The gills comprise five pleurobranchs corresponding to the five legs, a minute papilliform epipod on the third maxilliped, and four simple processes representing arthrobranchs attached to the third maxilliped and the first three legs, the most posterior being exceedingly minute. It is very probable that this rudimentary condition of the arthrobranchs is an indication of immaturity, for I find that in specimens of $P$. sivado of 20 millim. in length (i.e., not more than one third of the adult size) the three arthrobranchs, which in the adult are well-developed gills $*$, are represented by simple papillæ, while of the fifth pleurobranch, rudimentary in the adult, no trace can be detected. Although these specimens of $P$. sivado have assumed in most other respects the characters of the adult, there is no certainty that such is the case with the specimen now under consideration. All that can be said with regard to the latter is that while the absence of a mandibular palp and the characters of the other mouth-parts refer it to the genus Pasiphea, as limited by recent writers, the deep rostral tooth, the truncate telson, and the relative sizes of the chelipeds seem to differentiate it from all the species at present included in the genus.

\section{Family Acanthephyridx (?).}

Locality. Lat. $52^{\circ} 18^{\prime} \cdot 1 \mathrm{~N}$., long. $15^{\circ} 53^{\prime} \cdot 9 \mathrm{~W}$. Net no. $5 e$. 1070 fath. 21/11/98. One specimen.

The single specimen, about 13 millim. in length, bears a general resemblance to the group of larval forms for which Spence Bate founded his genus Caricyphus, and in particular to his C. gibberosus $\dagger$, with which it agrees especially in the broad laminar tooth with downwardly directed apex on the third abdominal somite. It differs in the stonter form of the body and in the relatively shorter carapace, which is only about one fourth of the total length. The rostrum is slender, slightly longer than the eyes, having seven teeth

* See the figure by Claus, "Neue Beitr. z. Morph. der Crust.," Arb.

Zool. Inst. Wien, vi. 1886, pl. iv. fig. 36 .

+ 'Challenger' Report, Macrura, p. 716, pl. exxi. fig. 4. 
above and one below. The number of gills could not be definitely ascertained, but there are five well-developed pleurobranchs and a single series of rudimentary arthrobranchs, as well as a series of epipods ceasing apparently on the third last leg. All the thoracic legs bear exopods, and the first two pairs are chelate.

Spence Bate's family Carycyphidæ*, being founded entirely on immature forms, cannot be sustained. It seems not unlikely that some at least of the species are larval Acanthephyrida, and in the present instance the arrangement of the gills lends some support to this view.

Distribution. Various forms referred to the "genus" Caricyphus were taken by the 'Challenger' in the Pacific, and by the Plankton Expedition in the Atlantic, in all cases at or near the surface.

Family Paguridæ.

Locality. Lat. $52^{\circ} 4^{\prime} \cdot 5 \mathrm{~N}$., long. $11^{\circ} 20^{\prime} \cdot 1 \mathrm{~W}$. Net no. 16 . 20 fath. 19/11/98. One specimen.

This specimen is a zoëa-larva at a stage in which none of the abdominal appendages are yct developed, although the telson bears seven pairs of spines instead of six as in the first stage of the Pagurid zoëa. It differs from the zoëa of Eupagurus bernhardus as described by Sars + in the shorter rostral spine and in the broader telson, the posterior margin of which is straight, not incised in the middle as in the earlier stages of that species, nor convex as in Anapagurus chiroacanthus.

LIX.-Report on the Coelenterata from the intermediate waters of the N. Atlantic, obtained by Mr. George Murray during the 'ruise of the 'Oceana' in 1898. By R. T. Günrher, M.A., Fellow of Magdalen College, Oxford.

[Plates IX. \& X.]

Althovgr a great deal of care was bestowed upon the collection and preservation of the material presently to be described, it was not easy to refer some of the individual specimens to their proper place in the system. Many of

* Op. cit. p. 927, Appendix B.

† "Bidr. til Kundskaben om Decapodernes Forvandlinger," Arch. f. Math. og Naturid, xiii, p. 146, pl, ii. (1890). 